\title{
ANALISIS STRUKTURAL DAN NILAI PENDIDIKAN KARAKTER DALAM NOVEL THE SUN OF THE RAIN KARYA VIONA PRAMESWARI
}

\author{
Cindy Viera Heryningtias ${ }^{1}$, Een Nurhasanah ${ }^{2}$, Slamet Triyadi ${ }^{3}$ \\ ${ }^{1}$ Universitas Singaperbangsa Karawang, Jl. HS.Ronggo Waluyo, Puseurjaya, Kec. Telukjambe Timur, \\ 1710631080042@student.unsika.ac.id \\ ${ }^{2}$ Universitas Singaperbangsa Karawang, , Jl. HS.Ronggo Waluyo, Puseurjaya, Kec. Telukjambe \\ Timur, een.nurhasanah@staff.unsika.ac.id \\ ${ }^{3}$ Universitas Singaperbangsa Karawang, , Jl. HS.Ronggo Waluyo, Puseurjaya, Kec. Telukjambe \\ Timur, Slamet.Triyadi@staff.unsika.ac.id
}

\begin{abstract}
Structural Analysis and the value of character education in The Sun Of The Rain Novel. Thesis of Indonesian Language and Literature Education Study Program. Faculty of Teacher Training and Education. Singaperbangsa Karawang University. This study aims to describe (1) the structure in the novel The Sun Of The Rain; (2) the values of character education contained in the novel The Sun Of The Rain. This research is a descriptive qualitative research with content analysis method. The results of the research are as follows: (1) Structural analysis; The theme of the novel The Sun Of The Rain is friendship and romance. The groove used is a mixed flow. There are main characters and additional characters in the characterizations. The setting used is time setting, place setting and social setting. The point of view used is the first person point of view as the main character. The style of language used is litotes, rhetoric, allegory; (2) The value of character education in the novel The Sun Of The Rain is responsibility, respect, courage, honesty, caring and perseverance. This research is also important to know how to analyze the structural and value of character education in a novel. As a knowledge of what structural and character education values are in the novel The Sun Of The Rain by Viona Prameswari.
\end{abstract}

Keywords: Structural analysis, the value of character education, the importance of analyzing.

\begin{abstract}
ABSTRAK
Analisis Struktural dan nilai pendidikan karakter dalam Novel The Sun Of The Rain. Skripsi Program Studi Pendidikan Bahasa dan Sastra Indonesia. Fakultas Keguruan dan Ilmu Pendidikan. Universitas Singaperbangsa Karawang. Penelitian ini bertujuan untuk mendeskripsikan (1) struktur yang ada di dalam novel The Sun Of The Rain; (2) nilai-nilai pendidikan karakter yang terapat di dalam novel The Sun Of The Rain. Penelitian ini merupakan penelitian yang bersifat deskriptif kualitatif dengan metode analisis isi. Hasil penelitiannya sebagai berikut: (1) Analisis struktural; tema novel The Sun Of The Rain adalah persahabatan dan percintaan. Alur yang digunakan adalah alur campuran. Penokohan nya terdapat tokoh utama dan tokoh tambahan. Pelataran yang digunakan adalah latar waktu, latar tempat dan latar sosial. Sudut pandang yang digunakan adalah sudut pandang orang pertama sebagai tokoh utama. Gaya bahasa yang digunakan adalah litotes, retorika, alegori; (2) Nilai pendidikan karakter yang ada di dalam novel The Sun Of The Rain adalah tanggung jawab, rasa hormat, keberanian, kejujuran, peduli dan ketekunan. Penelitian ini juga penting untuk mengetahui bagaimana caranya menganalisis struktural dan nilai pendidikan karakter dalam sebuah novel. Sebagai sebuah pengetahuan apa saja struktural dan nilai pendidikan karakter yang ada di dalam novel The Sun Of The Rain Karya Viona Prameswari.
\end{abstract}

Kata kunci: Analisis struktural, nilai pendidikan karakter, pentingnya menganalisis. 
How to Cite: Cindy, C. V. H., Een, E. N., \& Slamet, S. T. (2021). ANALISIS STRUKTURAL DAN NILAI PENDIDIKAN KARAKTER DALAM NOVEL THE SUN OF THE RAIN KARYA VIONA PRAMESWARI. Bahtera Indonesia; Jurnal Penelitian Bahasa Dan Sastra Indonesia , 6(2), 292-299. https://doi.org/10.31943/bi.v6i2.136

DOI: https://doi.org/10.31943/bi.v6i2.136

\section{PENDAHULUAN}

Sebuah karya sastra baik novel, cerpen maupun drama memiliki struktur di dalamnya. Struktur merupakan bagian-bagian yang saling berkaitan dan memiliki peran yang sangat penting dalam sebuah karya. Struktur ini mampu membuat sebuah karya menjadi satu kesatuan yang utuh.

Novel menjadi salah satu bagian dari karya sastra yang memiliki misi dalam ceritanya. Novel dapat digayakan, dipadatkan, serta diperkokoh kemampuan imajinasi dari penulisnya kepada pembaca. Karakteristik-karakteristik tokoh selalu ditampilkan di dalam sebuah novel. Cerita mengalir dari tokoh dalam cerita dan berakhir pada nasib yang dialami oleh tokoh.

Novel merupakan salah satu bentuk karya sastra yang dibentuk prosa yang didalamnya memiliki unsur-unsur, yaitu terdiri dari unsur intrinsik dan unsur ekstrinsik yang tentunya keduanya ini saling berkaitan dalam membentuk sebuah karya sastra.

Analisis struktural adalah suatu cara guna mengetahui secara teliti, unsur apa saja yang ada dalam sebuah karya sastra. Hal itu sangat tepat guna meneliti dan mengungkapkan makna karya sastra melalui pembahasan unsur-unsur yang saling berkaitan antara unsur yang satu dengan unsur yang lain secara struktural. Keseluruhan unsur yang membangun dalam pembentukan sebuah karya sastra ialah unsur yang ada di dalam karya sastra itu sendiri. Seperti halnya dengan pendapat yang diungkapkan oleh Culler, kalau cerita rekaan merupakan suatu sistem, maka subsistem yang terpenting di dalamnya adalah alur, tema, dan tokoh (Culler melalui Sudjiman, 1988:11)

Salah satu karya sastra yang memiliki nilai pendidikan karakter sehingga dapat memotivasi para pembaca yaitu novel The Sun of The Rain karya Viona Prameswari. Novel ini bercerita tentang kehidupan seorang gadis cantik yang bernama Rain yang pada saat itu sedang menempuh pendidikan di SMA. Sama dengan gadis lainnya, Rain memiliki banyak sahabat di sekolahnya, dia pun aktif dalam kegiatan akademik maupun non akademik. Karena parasnya yang cantik, Rain terkadang membuat kekacauan di sekolah. Banyak pria yang menyukai sosok 
Rain gadis cantik dan pintar. Namun Rain selalu menjadi sosok Rain yang biasa saja. Persahabatan Rain pun memiliki banyak cerita yang menarik perhatian teman-teman di sekolahnya. Namun, cinta segitiga hampir saja merusak persahabatan yang sudah dijalin sejak lama. Dibalik sosok nya sebagai gadis pintar di sekolah, Rain pun sangat menyayangi Ibunya. Karena hanya ibunyalah yang Rain punya saat ini. Viona Prameswari memperlihatkan banyak sekali nilai pendidikan karakter pada novelnya.

Penelitian bisa dikatakan baik yaitu penelitian yang mempunyai tujuan yang jelas. Adapun tujuan dari penelitian ini untuk mendeskripsikan (1) Struktur yang ada di dalam novel The Sun of The Rain karya Viona Prameswari; (2) Nilai pendidikan karakter yang terkandung di dalam novel The Sun Of The Rain karya Viona Prameswari.

\section{METODE PENELITIAN}

Penelitian ini adalah penelitian yang bersifat kualitatif. Metode kualitatif ini merupakan metode penelitian yang bersifat pengamatan. Dalam pengamatannya sendiri pun lebih focus kepada pengamatan yang mendalam, yang nantinya akan menghasilkan sebuah kajian. Sumber data yang langsung didapat dan diperoleh oleh peneliti dari sumber utamanya untuk keperluan penelitian, yaitu novel The Sun Of The Run karya Viona Prameswari yang diterbitkan oleh PT.
Gramedia Widiasarana yahun 2018 dengan jumlah halaman sebanyak 138 halaman. Novel The Sun Of The Rain ini merupakan novel dari Indonesia yang menceritakan tentang masa indah putih abu-abu, persahabatan, percintaan, pelajaran hidup dan pentingnya saling menghargai perasaan.

Metode analisis kualitatif ini diteliti dengan menggunakan novel The Sun Of The Rain karya Viona Prameswari sebagai objek penelitiannya. Penelitian ini dilakukan selama tujuh bulan lamanya, dimulai sejak bulan Desember 2020 hingga Juli 2021. Sumber data yang langsung didapat dan diperoleh oleh peneliti dari sumber utamanya untuk keperluan penelitian, yaitu novel The Sun Of The Run karya Viona Prameswari yang menceritakan tentang masa indah putih abuabu, persahabatan, percintaan, pelajaran hidup dan pentingnya saling menghargai perasaan. Teknik pengumpulan data ini menggunakan metode pengumpulan data dengan teknik baca simak catat yang meliputi pengumpulan data, mempelajari data, dan menganalisis data yang telah dikumpulkan dengan cara membaca, menyimak dan kemudian mencatat hasil analisis data, setelah mencatat hasil analisis data kemudian data yang diperoleh dideskripsikan sesuai dengan hasil analisis.

Fakultas Keguruan dan Ilmu Pendidikan 


\section{HASIL DAN PEMBAHASAN}

Pendekatan struktural dipelopori oleh kaum Formalis Rusia dan Strukturalisme Praha. Ia mendapat pengaruh langsung dari teori Saussure yang mengubah studi linguistik dari pendekatan diakronik ke sinkronik. Studi linguistik tidak lagi ditekankan pada sejarah perkembangannya, melainkan pada hubungan antarunsurnya. Masalah unsur dan hubungan antarunsur merupakan hal yang penting dalam pendekatan ini. Sebuah karya sastra juga memiliki sifat keotonomian, sehingga pembicaraan terhadapnya juga tak perlu dikaitkan dengan hal-hal lain yang di luar karya itu (Nurgiyantoro, 2012:36).

Analisis Struktural Novel The Sun Of The Rain

\section{Tema}

Nurgiyantoro

(2013:70) mengemukakan bahwa tema dapat dipandang sebagai dasar cerita, gagasan umum, sebuah karya sastra. Gagasan dasar umum yang telah ditentukan sebelumnya oleh pengarang inilah yang dipergunakan untuk mengembangkan cerita. Tema yang diangkat dari novel The Sun Of The Rain ini adalah perjuangan seorang sahabat yang merelakan kebahagiannya demi membahagiakan sahabatnya sendiri, walaupun memang harus ada perasaan yang dikorbankan. Berdasarkan tema tersebut, kisah dalam novel ini menggambarkan bahwa betapa dekatnya tokoh utama dengan sahabatnya yang setia menemani suka dan duka disetiap harinya,

\section{Pemplotan}

Alur atau plot adalah cerita yang berisi urutan kejadian, namun tiap kejadian itu hanya dihubungkan secara sebab akibat, peristiwab yang satu disebabkan atau menyebabkan terjadinya peristiwa yang lain (Stanton dalam Nurgiyantoro, 1995:113). Alur yang ada di dalam novel The Sun Of The Rain ini menggunakan alur campuran.

\section{Tokoh dan Penokohan}

Menurut Nurgiyantoro (2000), pengertian tokoh dapat dimaknai sebagai seorang atau sekelompok orang yang ditampilkan dalam suatu karya naratif dimana para pembaca dapat melihat sebuah kecenderungan yang dieskpresikan baik melalui ucapan maupun Tindakan. Tokoh yang di dalam novel The Sun Of The Rain ini yaitu, Rain, Daya, Bima, Bayu, Bu Nia, Meisa,Dinda, Arya, Masya.

\section{Pelataran}

Latar atau setting yang disebut juga sebagai landas tumpu, menyaran pada pengertian tempat, hubungan waktu, dan lingkungan sosial tempay terjadinya peristiwa-peristiwa yang diceritakan. Abrams (dalam Nurgiyantoro, 1995:216). Latar tempat yang ada di dalam novel The Sun Of The Rain yaitu di Sekolah, warung bubur ayam, Rumah Rain, Rumah Pintar, Warung 
Siomay, Cokelat Festival, Rumah Daya, pekerti yang menyentuh ranah kognitif,

Restoran, Rumah Bima, Rumah Sakit, Taman

Kota, Bandara, dan Kota Bali. Latar waktunya adalah pagi hari, sore hari dan malam hari. Serta latar sosianya meliputi kesederhanaan dan kemewahan.

\section{Penyudutpandangan}

Sudut pandang dalam karya fiksi mempersoalkan : Siapa yang menceritakan atau dari posisi mana (siapa) peristiwa dan tindakan itu dilihat. Pengertian sudut pandang adalah pada hakikatnya amerupakan staretegi, teknik, siasat, yang secara sengaja dipilih pengarang untuk mengemukakan gagasan ceritanya. Sudut pandang dapat disamakan artinya dan bahkan dapat memperjelas dengan istilah pusat pengisahan. Sudut pandang yang ada di dalam novel The Sun Of The Rain ini merupakan sudut pandang orang pertama. Karena disini penulis memposisikan dirinya sebagai tokoh yang terlibat dalam cerita.

\section{Bahasa}

Bahasa dalam novel The Sun Of The Rain ini menggunakan bahasa yang mudah di pahami oleh pembaca dari kalangan remaja, dewasa maupun orang tua. Kata-kata nya pun menggunakan bahasa Indonesia yang mudah dipahami oleh para pembaca. Bahasa yang digunakan adalah litotes, retorika dan alegori.

\section{Nilai Pendidikan Karakter}

Pendidikan karakter menurut Hamid dan Saebani (2013) adalah pendidikan budi afektif, dan psikomotorik. Pendidikan karakter menjamah unsur mendalam dari pengetahuan, perasaan, dan tindakan. Pendidikan karakter menyatukan tiga unsur tersebut. Secara akademik, pendidikan karakter dimaknai sebagai pendidikan moral, pendidikan watak, yang tujuannya mengembangkan kemampuan siswa untuk memberikan keputusan baik-buruk, memelihara yang baik dan mewujudkan kebaikan dalam kehidupan sehari-hari.

Aspek-aspek pendidikan karakter terdiri dari sembilan pilar yang saling terkait, yaitu :

a. Tanggung Jawab (responsibility), artinya menghadapi resiko dari perbuatan yang sudah dilakukan;

b. Rasa Hormat (respect), artinya bersikap sopan, etis, dan menghargai orang lain secara proposional;

c. Keadilan (fairness), artinya meletakkan segala sesuatu sesuai dengan porsinya, hidup tertib dan disiplin, tidak berpihak karena kepentingan yang menguntungkan diri sendiri, dan mentaati hukum tanpa pamrih dan penuh kesadaran dan keikhlasan;

d. Keberanian (courage), artinya berani menegakkan kebenaran atas nama kebenaran; 
e. Kejujuran (honesty), artinya menjauhkan diri dari sikap penuh dusta;

f. Kewarganegaraan (citizenship), artinya mengerti dan menjalankan kehidupan sosial-kemasyarakatan sebagai warga negara yang baik dan taat hukum;

g. Disiplin diri (self-discipline), artinya menjalani kehidupan dengan teratur dan terencana dan tidak bersikap sembrono, serta berhati-hati;

h. Peduli (caring), artinya berempati kepada nasib orang lain dan jika memiliki kemampuan ikut meringankan bebannya;

i. Ketekunan (perseverance), artinya memerhatikan dan mengambill pelajaran dari sisi positif dari semua pengalaman hidup, meningkatkan pemahaman kognitif terhadap semua pelajaran yang diperoleh dari bangku sekolah dan lingkungan masyarakat.

\section{Tanggung Jawab (responsibility)}

Nilai tanggung jawab yang ada di dalam novel The Sun of The Rain meliputi nilai-nilai tanggung jawab yang ditunjukkan oleh para tokoh. Ditunjukkan ketika Rain sebagai tokoh utama sedang sibuk dengan urusannya sebagai ketua jurnal. Itu artinya
Rain bertanggung jawab atas jabatan yang ia emban.

\section{Rasa Hormat (respect)}

Nilai pendidikan karakter selanjutnya yaitu rasa hormat. Yang mana nilai rasa hormat ini ditunjukkan di dalam novel The Sun Of The Rain. Ditimbulkan ketika tokoh utama Rain, berpamitan kepada ibunya. Sikap tersebut menunjukan bahwa Rain sebagai anak menghormati orang tuanya.

\section{Keberanian (courage)}

Nilai keberanian juga ada di dalam novel The Sun Of The Rain. Nilai keberanian ini ditunjukkan ketika tokoh Bima mengungkapkan perasaannya kepada Rain. Hal ini dapat disimpulkan bahwa tindakan Bima ini merupakan suatu keberanian.

\section{Kejujuran (honesty)}

Nilai pendidikan karakter selanjutnya yaitu kejujuran. Dimana dalam novel The Sun Of The Rain ini memiliki nilai kejujuran. Nilai kejujuran ini ditimbulkan ketika tokoh Bima mengungkapkan kejujuran perasaannya terhadap Rain.

\section{Disiplin diri (self-discpline)}

Nilai pendidikan karakter disiplin diri ada dalam novel The Sun Of The Rain. Ditunjukkan ketika tokoh Rain, Bima dan Daya sedang ada di dalam Perpustakaan. Kemudian mereka terlalu asyik berbicara sehingga mengganggu pengunjung yang lain. Tak lama mendapatkan teguran dari guru piket dan seketika itu Daya menutup 
mulutnya. Teguran dari guru piket mencerminkan ketegasan dalam berdisiplin.

\section{Peduli (caring)}

Nilai peduli yang ada di dalam novel The Sun Of The Rain ditunjukkan ketika tokoh Rain ingin meminta pulang kepada Bayu, karena dirasa Rain tidak tega meninggalkan ibunya di rumah sendirian. Hal ini menunjukkan bahwa Rain peduli terhadap ibunya.

\section{Ketekunan (perseverance)}

Nilai ketekunan yang ada di dalam novel The Sun Of The Rain ditunjukkan ketika tokoh Rain memenangkan lomba dan mengharumkan nama sekolahnya. Hal ini menunjukkan bahwa tokoh Rain tekun dalam belajar. Karena ketekunan nya Rain berhasil memenangkan lomba.

\section{SIMPULAN}

Berdasarkan hasil analisis dan pembahasaan mengenai data, penulis memperoleh kesimpulan yang dapat diambil dari penelitian mengenai "Analisis Struktural dan Nilai Pendidikan Karakter Dalam Novel The Sun Of The Rain Karya Viona Prameswari sebagai berikut :

1. Hasil dari penelitian ini menunjukkan bahwa analisis struktural dalam novel The Sun Of The Rain dapat ditemukan dengan mudah, dengan mengumpulkan data-data yang sudah di analisis.
2. Hasil strktural yang ditemukan diantarnya tema novel The Sun of The Rain adalah persahabatan dan percintaan. Alur yang digunakan adalah alur campuran. Penokohan nya terdapat tokoh utama dan tokoh tambahan. Pelataran yang digunakan adalah latar waktu, latar tempat dan latar sosial. Sudut pandang yang digunakan adalah sudut pandang orang pertama sebagai tokoh utama. Gaya bahasa yang digunakan adalah litotes, retorika, alegori.

3. Nilai pendidikan karakter yang ada di dalam novel The Sun Of The Rain adalah tanggung jawab, rasa hormat, keberanian, kejujuran, peduli dan ketekunan.

4. Hasil penelitian nilai pendidikan karakter ini dapat ditemukan dengan mudah ketika sudah menganalisis unsur struktural novel The Sun Of The Rain.

\section{DAFTAR PUSTAKA}

Dwi Susanti, Kusumaning.(2013). Analisis Struktural Dan Kajian Religiusitas Tokoh Dalam Novel Rumah Tanpa Jendela Karya Asma Nadia . 1-11.

Fauziyah, NF. (2016). Bab II Landasan Teori. Diakses dalam laman eprints.walisongo.ac.id. (22 Maret 2021).

Hartini, Siti. (2017). Bab II. Diakses dalam laman https://123dok.com/document/downl $\mathrm{oad} / \mathrm{z} 1 \mathrm{de} 4 \mathrm{pz}$ ?page $=1 \#$ =

Istiaisyah. (2013). Teori Sastra Strukturalisme. (Online). 
Tersedia:

http://iissitiaisyahinfo.blogspot.com/2 013/02/teori-sastra

strukturalisme.html?m=1. (10 Maret 2021).

Nurgiyantoro, Burhan. (2009). Teori Pengkajian Fiksi. Yogyakarta. Gadjah Mada University Press.

Psikologi, Universitas. (2020). Pengertian Pendidikan Karakter dan Aspeknya Menurut Para Ahli. (Online). Tersedia https://www.universitaspsikologi.co $\mathrm{m} / 2019 / 11 /$ pengertian-pendidikankarakter-dan-aspek-karaktermenurut-

ahli.html?m=1\#: :text=Menurut $\% 20$

Kaimuddin\%20(2014)\%20pendidika n\%20karakter,konstruktif\%20pada\% 20alam\%20dan\%20masyarakat

Prameswari, Viona. (2018). The Sun Of The Rain. PT Grasindo. Jakarta.

Maulina, Murni. (2019). Analisis Strukturalisme Todorov Pada Cerpen "Monolog

Kucing" Karya Gilang Rahmawati. Diakses dari laman http://proceedings.upi.edu/index.php/ riksabahasa/article/view/1090. (12 Juli 2021)

Ratna, Nyoman Kutha. (2012). Teori, Metode dan Teknik Penelitian Sastra. Pustaka Pelajar.

Salimudinzuhdi. (2017). Teori Strukturalisme Dalam Sastra. (Online). Tersedia: https://salimudinzuhdi.wordpress.co $\mathrm{m} / 2014 / 01 / 09 /$ teori-strukturalismedalam-sastra/. (10 Maret 2021).

Thabroni, Gamal. (2019). Sastra-Pengertian, Sejarah, Jenis \& Fungsi (Pendapat Ahli). (Online). Tersedia : https://serupa.id/sastra-pengertian- sejarah-jenis-fungsi/. (22 Maret 2021).

Yiquan, Lia. (2017). Analisis Unsur Intrinsik Novel Habibie dan Ainun Sebagai Upaya Pembentukan Karakter Bangsa. Diakses dari laman repository.unpas.ac.id/29050/8. (09 Februari 2021). 